\title{
O TERRITÓRIO COMO UM ELEMENTO INDISSOCIAVEL DA EDUCACÃO: UM DESAFIO PARA A FORMAÇÃO DE PROFESSORES INDÍGENAS
}

\author{
THE TERRITORY AS AN INSEPARABLE ELEMENT OF EDUCATION: A CHALLENGE \\ FOR FORMATION OF INDIGENOUS TEACHERS \\ EL TERRITORIO COMO UN ELEMENTO INDISOCIABLE DE LA EDUCACIÓN: UN \\ RETO PARA LA FORMACIÓN DE PROFESORES INDÍGENAS
}

Maria Aparecida Rezende* rezemelo@gmail.com

\begin{abstract}
REVISTA PEDAGÓGICA
Revista do Programa de Pós-graduação em Educação da Unochapecó | ISSN 1984-1566 Universidade Comunitária da Região de Chapecó | Chapecó-SC, Brasil Como referenciar este artigo: REZENDE, M. A. O território como um elemento indissociável da educação: um desafio para a formação de professores indígenas. Revista Pedagógica, Chapecó, v. 17, n. 34, p. 75-91, jan/abr.2015.
\end{abstract}

RESUMO: Este texto é uma provocação de diálogo com as instituições que se propôs a oferecer a Formação de Professores Indígenas. Também tem a intenção de discutir o lugar do território como um dos eixos que sustentam a cultura dos povos indígenas por meio da educação. Juntar a educação escolar à educação indígena e, a partir disso, compreender o que é educação intercultural. Essa discussão foi realizada junto aos povos indígenas e com a assessoria pedagógica no seio das aldeias mato-grossenses, escutando as vozes sempre silenciadas. A partir dessa escuta, necessitou-se de muitas leituras e trocas de experiências com pessoas que partilham desse mesmo problema. O desafio é da efetivação das práticas pedagógicas interculturais. Não se separa a educação da vida. E o território é o coração da educação indígena.

PALAVRAS-CHAVE: Formação de professores. Território. Educação indígena. Interculturalidade.

ABSTRACT: This text is a dialog provocation with the institutions that purport to offer Formation Indigenous Teachers. Also intends to discuss the place of territory as one of the axes that sustain the culture of indigenous peoples by means of education. Join education to indigenous education and from that understand what is intercultural education. This discussion was held with the indigenous peoples and the pedagogical support within Mato Grosso villages, listening the voices silenced always. From that listening is required many readings and exchange of experiences with people who share this same problem. The challenge is the effectuation of intercultural pedagogical practices. Does not separate education of life, and the territory is the heart of indigenous education.

KEYWORDS: Teacher Formation. Territory. Indigenous education. Interculturality.

RESUMEN: Este texto es una provocación al diálogo con las instituciones que se propusieran a ofrecer la formación de profesores indígenas. El también presenta la intención de discutir el lugar del territorio como uno de los ejes que sostienen la cultura de los pueblos indígenas mediante la educación. Unir la educación escolar a la educación indígena y desde ahí comprender lo que es la educación intercultural. Esta discusión se llevó a cabo junto con los pueblos indígenas y con la asesoría pedagógica en el centro de la aldea matogrossense, escuchando las voces que siempre fueron silenciadas. A partir de la escucha, se hizo necesaria muchas lecturas y cambios de experiencias con las personas que compartían del mismo problema. El reto es la realización de las prácticas pedagógicas interculturales. No se separa la educación de la vida. Y el territorio es el corazón de la educación indígena.

PALABRAS CLAVE: Formación de profesores. Territorio. Educación Indígena. Interculturalidad. 
* Doutora pela Universidade Federal de Mato Grosso. Atualmente é professora da Universidade Federal de Mato Grosso. Tem experiência na área de Educação, com ênfase em educação indígena, educação escolar indígena e educação de jovens e adultos.

\section{INTRODUÇÃO}

O objetivo desse texto é trazer três assuntos que têm provocado debates calorosos no contexto acadêmico, nas formações específicas de professores indígenas, nas aldeias, ainda que a abordagem seja de outra forma e com outras intenções. Os três assuntos - território, educação indígena e educação escolar indígena - pouco a pouco serão diluídos ao longo desta discussão.

As formas de tratá-los são diversificadas a depender do contexto e do lugar em que são inseridas. Antes de dar continuidade nessa especificidade, é importante fazer uma rápida contextualização da história da educação escolar para os povos indígenas até chegar ao ponto da nominação de educação escolar indígena.

Várias publicações sobre o período colonial informaram sobre a triste intencionalidade da catequese dos povos indígenas. A história oficial sempre ocultou ou mascarou as vivências de subalternas posições dos grupos sociais que sofreram os horrores da discriminação pelas interpretações das ideologias que se julgaram superiores aos outros conhecimentos e saberes.

A perversa realidade é evidenciada nas pesquisas de vários arqueólogos, os quais revelam números assustadores de pessoas que habitavam o Brasil antes da sua invasão. O etnólogo Curt Nimuendaju (2006, p. 21) assinalou, em seu mapa etno-histórico, cerca de 1.400 povos indígenas em território brasileiro. Atualmente, pode-se contar com um número restrito desses povos em relação numérica com o passado do Brasil Colônia.

Ao longo dos anos, essa história foi modificada pelo Movimento Indígena e pelos aliados a essa causa. A partir daí, a história da escolarização foi tomando longos caminhos em busca de uma educação escolar que respeitasse as diversidades culturais, religiosas e sociais de cada povo. Na mesma proporcionalidade, os Movimentos Indígenas e aliados foram discutindo a possibilidade do retorno dos diversos territórios invadidos ao longo dos anos. As conquistas de recuperação de territórios não foram descoladas da educação indígena. Por quê? Porque o território faz parte da educação de cada povo.

Desse modo, esses três temas voltam, também, nesse texto e serão de outras formas mencionados, ainda que já abordados em outras publicações dessa mesma autoria. A educação indígena fortalece a cultura, a religiosidade e as vivências étnicas; por isso, a educação escolar precisa respeitar a atuação da ação pedagógica dos povos indígenas que permaneceram com suas línguas, suas tradições e seu orgulho de pertença étnica.

\section{EDUCAÇÃO E TERRITÓRIO INDÍGENA}

O que é educação indígena? Vários antropólogos, linguistas, educadores, religiosos, ousaram dizer o que é essa educação a partir de vivências de trabalho com comunidades 
indígenas, pela parca experiência de observação por meio da pesquisa. Enfim, são várias as compreensões. Em primeiro lugar, tomamos os versos do poeta sertanejo Patativa do Assaré (2011, p. 25-26) ele mostra de modo simples e, com uma profundidade, o que é essa educação.

Se aí você teve estudo, aqui Deus me ensinou tudo, sem de livro precisá, por favo não mexa aqui, que eu também não mexo aí, cante lá que eu canto cá. Você teve inducação, aprendeu munta ciença, mas das coisas do sertão não tem boa esperiença. Nunca fez uma paioça, nunca trabaiou na roça, não pode conhecê bem, pois nesta penosa vida, só quem provou da comida, sabe o gosto que ela tem.

Mesmo vivendo por um tempo junto às comunidades indígenas, o sentimento desse jeito de ser e viver não é o mesmo, pois a "pertença" é de outro grupo. A pessoa nasce, cresce e morre tendo aqueles costumes. $\mathrm{O}$ que se entende por educação indígena é uma aproximação a partir do olhar do Outro e daquilo que as retinas revelam naquele contexto, naquele período, naquele lugar. Dessa forma é possível descrever o que é educação indígena; mas, como diz Assaré (2011) "[...] só quem provou da comida, sabe o gosto que ela tem".

É preciso viver, sentir e ter a sensibilidade de passar para o papel, por meio da escrita, aquilo que se viu, presenciou, observou, o modo corpóreo das vidas ali presentes. Isso porque, de acordo com a fenomenologia merleaupontyana, o corpo revela gestos e sentidos interligados com o mundo no contexto das suas significações de vida nesse mundo (MERLEAU-PONTY, 1991, 2006, 2009).

Essa educação, desde o período colonial, representa uma ameaça até hoje à sociedade vigente. É um modo educacional que não visa ao lucro, ao consumo e a relações de poder no sentido de disputar um bem para o enriquecimento. Sabe-se que a educação de um povo é o que aquela sociedade se percebe enquanto homem e mulher e naquela visão de mundo. Nesse sentido - e inspirado no filósofo Agamben -, Ruiz (2012, p. 19) assim interpreta essa ameaça,

Quando uma pessoa ou grupo populacional se torna uma ameaça para a ordem, o Estado utiliza-se da exceção jurídica para separar os direitos da cidadania da mera vida nua. Esta separação possibilita expulsar para fora do direito a vida que se pretende controlar na forma de exceção. Na exceção, o direito suspenso torna a vida humana um homo sacer, exposto à fragilidade da violação sem que 0 direito possa ser invocado para protegê-lo.

A prova viva desses direitos suspensos é a morte das diversas lideranças indígenas do país. Todas elas sem nenhuma preocupação do Estado com uma averiguação 
jurídica e em punir os assassinos. A exemplo, pode-se ler quase toda semana notícias sobre o assassinato de um homem ou mulher que atuava como liderança do povo Guarani e Kaiowá. Seus direitos foram suspensos. Assim, vivem na fragilidade e tornam-se vítimas de todas as formas de violência. O homo sacer, na compreensão de Agamben, citado por Ruiz (2012, p. 33) trata-se da "vida abandonada pelo direito".

A particularidade do homo sacer é que ele é incluído pela exclusão e excluído de forma inclusiva. Esta figura paradoxal captura a vida humana pela exclusão ao mesmo tempo em que a inclui pelo abandono. É uma vida matável por estar fora do direito, mas por isso mesmo ela não pode ser condenada juridicamente.

Essa "vida matável" refere-se a todos os grupos sociais excluídos e abandonados, e soma-se a eles as pessoas que moram ou vivem na e da rua, e que, por isso, representam ameaça à sociedade vigente. Estão fora das normas. Vivem nesses espaços da rua em uma condição de vida nua. Ferreira (2012, p. 41) também aborda o entendimento de Agamben sobre "vida nua": "[...] aquela que qualquer um pode tirar sem cometer homicídio ou aquela que qualquer um pode levar à morte, em que pese seja insacrificável". Assim, pode-se perceber que a "vida nua" é a vida exposta à morte.

É notável proibirem o modo educacional dos povos indígenas justifica-se por que estes estavam incomodando aos padrões da sociedade da época. A educação étnica não se enquadra dentro dos valores da sociedade ocidental capitalista. Ao contrário disso, o movimento atual é que essa educação passe a orientar a educação do mundo ocidental, iniciando-se pela interação da educação indígena e da educação escolar.

O linguista e antropólogo Meliá (1999, p. 11) registrou que, ao contrário daqueles que pensam que a educação indígena é um problema ela é a solução para nossa educação. Em suas palavras:

Os povos indígenas mantêm sua alteridade graças a estratégias próprias de vivência sociocultural, sendo a ação pedagógica uma delas. A educação desenvolvida pelos povos indígenas lhes permite que continuem sendo eles mesmos e mantenham a transmissão de suas culturas por gerações. Neste trabalho mantém-se o pressuposto de que não há um problema da educação indígena, pelo contrário, o que existe é uma solução indígena ao problema da educação.

Cônscio dessa mesma afirmação, sabe-se que a educação indígena é forte porque as pessoas dos grupos étnicos acreditam nela, confiam nela, sabem que ela é capaz 
de ser dinâmica, movimentar-se de acordo com o tempo e, mesmo assim, ela se mantém em essência. Para entender o que é essa ação pedagógica usada milenarmente pelos povos indígenas Meliá (1999, p. 13) comenta que a ação pedagógica tradicional.

[...] integra sobretudo três círculos relacionados entre si: a língua, a economia e o parentesco. São os círculos de toda cultura integrada. De todos eles, porém, a língua é o mais amplo e complexo. O modo como se vive esse sistema de relações caracteriza cada um dos povos indígenas. $\mathrm{O}$ modo como se transmite para seus membros, especialmente para os mais jovens, isso é a ação pedagógica.

Ele coloca a língua como um elemento importante dessa ação pedagógica. Só compreendi essa afirmação quando observei que, no cotidiano das aldeias, as pessoas se comunicam na língua e mesmo quando não falam a língua, como me disse certa vez uma senhora Umutina: "Professora, mesmo não falando a língua, o jeito de cada povo falar é diferente do outro".

O professor Osvaldo da etnia A'uwẽ, em seus estudos com a língua do seu povo, disse-me que, de uma região para outra, as pessoas modificam sua maneira de falar. Por exemplo, as mulheres de uma dessas regiões falam mais fino. Isso muda toda a estrutura e a compreensão da língua A'uwẽ, segundo ele. Meliá (1999) faz essa afirmação de um modo mais profundo, uma vez que suas vivências com os Guarani por tantos anos o fizeram perceber que, para esse povo, a língua carrega o espírito da pessoa. É por meio da língua que as pessoas aprendem e ensinam. Somados a esses aprendizados estão todos os elementos da cultura, da religiosidade, dos costumes e das tradições de um povo.

A educação indígena é amorosa, mas também rigorosa. Ela segue suas normas, seus padrões, respeitando a limitação de cada pessoa. Espera o tempo de cada um e cada uma. É uma educação cíclica que sabe o homem e a mulher que se quer formar. Seus valores são ressaltados, mas também aceitam o novo com muita facilidade e sem ferir seus princípios educativos. Eles aprenderam isso com os mais de 500 anos de violência linguística, cultural e social.

Após a Constituição Federal de 1988, os povos indígenas saíram dos seus esconderijos. Há um discurso recorrente e repassado adiante da sociedade ocidental brasileira de que "agora todo mundo quer ser índio, só para tomar terra dos outros". Certamente, esse é um discurso vazio de conteúdo, pois tais pessoas que proferem esse julgamento ignoram a verdadeira história do Brasil. Repetem palavras ouvidas das pessoas que adotaram as práticas de dominação e ainda "vestem a roupa colonialista" dos que querem mandar, além de continuar "mandando", assumir direitos que se pode ser compreendido como invasores. 
Atualmente, os povos indígenas se orgulham de sua pertença étnica. Não há perigo de repressão. O antropólogo da etnia Baniwa Luciano (2006, p. 39) faz a seguinte afirmação:

Culturas e tradições estão sendo resgatadas, revalorizadas e revividas. Terras tradicionais estão sendo reivindicadas, reapropriadas ou reocupadas pelos verdadeiros donos originários. Línguas vêm sendo reaprendidas e praticadas na aldeia, na escola e nas cidades. Rituais e cerimônias tradicionais há muito tempo não praticados estão voltando a fazer parte da vida cotidiana dos povos indígenas nas aldeias ou nas grandes cidades brasileiras.

Os povos indígenas agora gritam por seus direitos porque têm leis que os apoiam. Entretanto, ainda assistimos a tantos assassinatos por causa dessas reivindicações de direitos de cidadãos. Muitas pessoas, para sobreviverem, ocultaram sua etnia e tudo isso como uma arma de sobrevida. Mas, em seu íntimo, todas elas sabiam que tinham outra forma de vida. Em casa muitos aprendiam suas línguas, ouviam suas histórias, recebiam dos mais velhos sua religiosidade, ainda que, externamente, praticassem outra religião.

A educação de cada povo varia com o modo de se organizarem socialmente, como Luciano (2006, p. 44-45) explica:

Toda organização social, cultural e econômica de um povo indígena está relacionada a uma concepção de mundo e de vida, isto é, a uma determinada cosmologia organizada e expressa por meio dos mitos e dos ritos. As mitologias e os conhecimentos tradicionais acerca do mundo natural e sobrenatural orientam a vida social, os casamentos, $o$ uso de extratos vegetais, minerais ou animais na cura de doenças, além de muitos hábitos cotidianos.

Essas informações já mostram a diferença da educação indígena. Ela interage com todos os elementos da vida em seu seio. $\mathrm{O}$ mundo animal de todas as espécies e não somente a humana, o respeito com todos os seres. Também fazem parte do princípio educativo os valores sociais, culturais e religiosos. Não há um querer de formação única para todas as etnias. Cada etnia tem seu modo de educar. Já a educação da sociedade ocidental brasileira pretende uma formação homogênea, sem respeitar as diferenças de cada pessoa.

Essa educação silenciada por tantos anos volta agora a reivindicar seus direitos. É importante, por isso, observar a compreensão merleaupontyana. O filósofo Francês Merleau-Ponty (2006), acredita que o silêncio é cheio de ruídos, as palavras estão lá, desejando ser externalizadas; 
mas, muitas vezes, são inúteis, pois não são ouvidas e, também, há receio e desconfiança para dizê-las. Nesse silêncio ruidoso, apelamos para a sensibilidade dos sentidos, que é mais do que o uso dos cinco sentidos, mas o sentimento de olhar para outro que é o "Outro de mim".

Boaventura de Sousa Santos (2014) descreve como o silêncio é negligenciado como objeto de investigação na sociedade ocidental, expondo essa compreensão em quatro razões, distribuídas ao longo das páginas de seu livro, as quais nos auxiliarão na interpretação do fenômeno percebido. Quanto à relação entre o silêncio e a linguagem, de acordo com esse autor, "[...] o silêncio é uma realidade tão significativa e comunicativa como a própria linguagem" (p. 132-134). Muitas pessoas no silêncio mostram seus sentimentos. Por isso, é importante trazer as variadas razões que Santos descreve sobre a negligência do silêncio enquanto método de investigação. "O estudo sociológico do silêncio constitui uma ameaça não só às fronteiras científicas aceitas, mas também aos métodos científicos da investigação sociológica" (SANTOS, 2014, p. 132-134). No ocidente, os estudos foram desenvolvidos por meio do comportamento da linguagem e o silêncio pode ser uma ameaça a essa investigação.

Os cientistas sociais, sentem-se, mais à vontade quando especulam com palavras sobre palavras, de que quando especulam com palavras sobre o silêncio". Isso porque se compreende que é mais fácil de controlar as palavras do que o silêncio. "Ainda não foi demonstrada a utilidade dos estudos sobre o silêncio, nem o será enquanto os ritmos linguagem/silêncio nas diferentes sociedades, não começarem a ser descodificados. (SANTOS, 2014, p. 132-134).

A sociedade ocidental, como afirma Santos (2014), discrimina a investigação usando um método como o silêncio.

Desse modo, essa educação indígena de cada povo, suas histórias, seus mitos, sua cultura, seus rituais, enfim, todos esses elementos necessitam de outro fundamental que é a chave que abre as portas para a formação do homem e da mulher étnicos: o território. Sem ele, as pessoas ficam perdidas, deprimidas. Não sabem como dar continuidade na educação dos seus filhos, dos seus netos se faltam os recursos naturais e o diálogo com a Mãe Terra e todos os seres vivos e não vivos do conjunto que faz parte o território.

\section{O TERRITÓRIO}

O território é parte da organização social de cada povo. O antropólogo Luciano (2006, p. 44) mostra que a vida e a compreensão política estão em consonância com os grupos sociais hierárquicos denominados sibs, fratrias ou tribos. Para entender, 
Fratria ou sib é uma espécie de linhagem social dentro do grupo étnico, que está relacionada direta ou indiretamente à origem do povo ou à origem do mundo, quando os grupos humanos receberam as condições e os meios de sobrevivência. Os sibs ou fratrias são identificados por nomes de animais, de plantas ou de constelações estelares que, por si só, já indicam a posição de hierarquia na organização sociopolítica e econômica do povo.

Entendemos essa relação da vida com o mundo, essa não divisão, essa hierarquia sem a presença da dominação, mas como modo de organização social. Para o filósofo Merleau-Ponty (2006, p. 6-8) homem e mundo são unos, são vistos dissociados somente pela filosofia ocidental, fortalecida pela concepção indo-europeia. Não existem separadamente, pois há, entre ambos, uma relação de entrelaçamento que não destrói as diferenças, porque estas só podem ser concebidas em uma interdependência em que a destruição completa de uma implica o desaparecimento completo da outra, pois os que as constitui é a relação. Conforme Merleau-Ponty (2006, p. 6-8):

O mundo [...] é o meio natural e o campo de todos os meus pensamentos e de todas as minhas percepções explícitas. A verdade não "habita" apenas o "homem interior", ou antes, não existe homem interior, o homem está no mundo, é no mundo que ele se conhece. [...] O mundo está ali antes de qualquer análise que eu possa fazer dele [...] o real deve ser descrito e não construído. O mundo é aquilo mesmo que nós nos representamos não como homens ou como sujeitos empíricos, mas enquanto participamos do uno sem dividi-lo.

O mundo, portanto, não é separado do meu eu, estamos todos juntos. Antes de mim, já existia o mundo. Um exemplo dessa unidade entre "mundo-eu-nós" são as relações que os povos nativos estabelecem com os animais, com as plantas, com as constelações. Por exemplo, quando a lua está em determinada posição não é hora de tirar a palha para cobrir a casa, pois aquilo que diminui a alteridade implica minha própria destruição e aquilo que fortalece a complementaridade se irradia, entre diversos outros saberes interligados com a vida, com o mundo.

O geógrafo Caron (2012) escreveu um fascículo de Geografia para os estudantes do Curso de Pedagogia a Distância do Núcleo de Educação a Distância no Instituto de Educação da Universidade Federal de Mato Grosso. Nesse material ele descreve de um modo simples, para que os estudantes compreendam, o que ele chama de conceito de território. Assim, território implica

[...] a posse de um determinado espaço, decerto, mas o caráter desta posse assume 
diferentes significados práticos e históricos. Se partirmos de um conceito puramente biológico, o conceito de território está presente em todos os animais, dada as inúmeras formas de demarcação no espaço real de sobrevivência, desde o menor e mais simples inseto ao mais complexo dos mamíferos, passando por peixes, aves e répteis. $\mathrm{O}$ homem, na sua complexidade cultural, é o único a organizar o território com base na ancestralidade territorial e linguística anterior (CARON, 2012, p. 104).

Interessante essa leitura de território. Aqui abrange o território com foco nos seres vivos, não vivos e também aos seres visíveis e invisíveis, como entende Merleau-Ponty, que afirma:

O sentido é invisível, mas o invisível não é o contraditório do visível: o visível possui, ele próprio, uma membrura de invisível, e o in-visível são a contrapartida secreta do visível, não aparece senão ele não se pode vê-lo aí, e todo esforço para aí vê-lo o faz desaparecer, mas ele está na linha do visível, é a sua pátria virtual, inscreve-se nele (2009, p. 200).

Não se pode considerar o invisível como algo inexistente como querem diversas pessoas que afirmam: "se não vejo, a coisa não existe". Merleau-Ponty (2009) mostra que não há como separar as duas coisas, elas estão juntas. O invisível está na linha do visível. Ele existe. É com esse olhar que os povos indígenas enxergam e organizam seu mundo.

O geógrafo Caron faz uma ligeira abordagem sem se aprofundar na questão de território; porém, em minha leitura e convivência com alguns povos indígenas, posso compreender essa ancestralidade territorial como a presença de muitas coisas que não vemos.

A antropóloga Gallois ([s. d.], p. 41) discute a ideia de território também usando a palavra espaço.

O espaço pode ser o ponto de partida para pensar o território, enquanto suporte físico que é territorializado: relações são estabelecidas, criando limites e canais de comunicação, proximidades e distâncias, interdições, fronteiras seletivamente permeáveis conforme a lógica territorial do grupo que territorializa uma dada porção de espaço.

Essa noção de território permite compreender a relação dos limites de terra como espaço que cada povo pode usufruir e travar diálogo com outros espaços.

O filósofo Merleau-Ponty (2006) compreende o espaço de um modo profundo, reconhecendo esse espaço como uma constituição de um mundo pleno e não dividido. Ele faz uma abordagem do nível espacial, comentando que 
podemos fazer uma leitura do território de uma maneira mais próxima da compreensão dos povos indígenas.

A constituição de um nível espacial é apenas um dos meios da constituição de um mundo pleno: meu corpo tem poder sobre o mundo quando minha percepção me oferece um espetáculo tão variado e tão claramente articulado quanto possível, e quando minhas intenções motoras, desdobrando-se, recebem do mundo as respostas que esperam. Esse máximo de nitidez na percepção e na ação define um solo perceptivo, um fundo de minha vida, um ambiente geral para a coexistência de meu corpo e do mundo. Com a noção do nível espacial e do corpo enquanto sujeito do espaço, compreendem-se os fenômenos. (MERLEAU-PONTY, 2006, p. 337-338).

A relação corpórea das pessoas ocorre de acordo com sua percepção de mundo. Merleau-Ponty (2009, p. 136), de outra forma e com outras palavras, possibilita várias maneiras de interpretar o espaço e compreender os fenômenos. Nesse mesmo parágrafo, ele complementa essa noção de espaço "[...] tudo nos reenvia as relações orgânicas entre o sujeito e o espaço, a esse poder do sujeito sobre seu mundo que é a origem do espaço". Esse poder está interligando carnalmente esses sujeitos com o mundo e, em particular, com sua compreensão de espaço.

Para esse filósofo, a carne seria como o quinto elemento fundamental para a vida. Ele considerava como essenciais: o ar, o sol, a terra, o fogo e a carne.

A carne não é matéria, não é espírito, não é substância. Seria preciso, para designá-la o velho termo "elemento", no sentido em que era empregado para falar-se da água, do ar, da terra e do fogo, isto é, no sentido de uma coisa geral, meio caminho entre o indivíduo espácio-temporal (sic) e a idéia (sic), espécie de princípio encarnado que importa um estilo de ser em todos os lugares onde se encontra uma parcela sua. Neste sentido, a carne é um "elemento" do Ser. Não fato ou soma de fatos e, no entanto, aderência ao lugar e ao agora (MERLEAU-PONTY, 2009 p. 136).

Nesse entendimento, pode-se considerar que a carne está em interação com todo o mundo. E mais, faz parte do Ser. É esse sentimento que os povos indígenas têm em relação aos seus espaços, ao seu território. Não é só pela terra, mas por tudo que a envolve e representa vida. E essa vida é a própria educação. Os indivíduos de uma etnia, mesmo antes do nascimento, já começam a ser educados pelos pais, pelos avós, pela ancestralidade. Existe uma aderência ao lugar que considera seu, mas que partilha com todos os outros seres. 
Por toda essa discussão, é fácil compreender a importância do território para os povos indígenas. Ele não está separado da vida. É o mundo onde se pode sonhar, viver uma relação educacional e poder fortalecer a cultura, a religiosidade, os costumes e dar significado para esse mundo. Alcançar a significação desse mundo e a relação com todos os seres. Os sentidos que os povos étnicos dão para o território está para além da compreensão da ciência ocidental. É por isso que os conflitos entre as sociedades indígenas e a sociedade ocidental vêm aumentando cada vez mais.

Para os grupos que conflitam com os povos indígenas, o território não passa de terra fértil que precisa produzir para levar toda a nação à frente: representa riqueza, lucro e desenvolvimento do país. Para os povos indígenas, o que há é uma grande violência contra a Mãe Terra, responsável pelo alimento dos seres vivos. As derrubadas das árvores significam uma invasão à vida. O plantio monocultural em grande escala é um desrespeito contra a vida de todos os habitantes desse território. Todos os animais são mortos, não para servirem de alimentos, mas para desocupar um espaço que também é deles e dar lugar, por exemplo, à soja, à cana-de-açúcar e às pastagens. É por essa e outras razões que o linguista Meliá (1999, p. 11) afirmou que “[...] não há um problema da educação indígena, pelo contrário, o que existe é uma solução indígena ao problema da educação".

\section{FORMAÇÃO DE PROFESSORES INDÍGENAS E A EDUCACAÇÃO ESCOLAR INDÍGENA}

Foram discutidos anteriormente dois aspectos interligados à vida dos povos indígenas: a educação indígena e o território. Nesta seção, ainda que timidamente, trataremos da escolarização "para índios", da educação escolar indígena e da responsabilidade das universidades que têm cursos específicos étnicos e/ou vagas adicionais.

É sabido que, com a entrada dos jesuítas no Brasil, iniciou-se uma escolarização com o intuito de catequizar os povos indígenas. Até a expulsão dos jesuítas, esse trabalho era realizado de acordo com o Estado.

A antropóloga Amoroso (2001), ao fazer uma análise dos dispositivos institucionais (plano de legislação indigenista do Segundo Reinado), descobriu que tal plano justificava a manutenção das escolas em aldeamentos e a sua finalidade. Assim, destacou a situação dos aldeamentos do Paraná e o sentido da catequese e da civilização para os Guarani, Kaiowá e Kaingang aldeados no século XIX. Segundo a antropóloga, quando escolas foram implantadas em áreas indígenas buscavam atender demandas muito claras.

Sua existência era emblemática da política indigenista da época, que se erguia sobre os pilares da catequese e da civilização e pautava-se por um conjunto de princípios que 
girava em torno da conversão, educação e assimilação branda da população indígena ao conjunto da sociedade nacional. [...] Gerado pela política da brandura, o texto da lei de 1845 continha na sua pragmática assimilacionista o germe de novas formas de violências. (AMOROSO, 2001, p. 136-137).

Essa política da brandura, no entanto, continuou com a violência da assimilação. Era preciso que os povos indígenas aceitassem a religião da sociedade ocidental e também que aprendessem a viver como os "civilizados". E, neste momento, se fecha o parêntese da escolarização por meio das missões religiosas e começa uma nova fase desse período escolar: a fase em que surgem projetos alternativos de educação escolar com a participação de organizações não governamentais e dos movimentos indígenas.

Organizações religiosas ou não, no final da década de 1970, começaram a agir em defesa das inúmeras causas indígenas. A partir dessa época, apesar de o país estar enfrentando uma ditadura militar, os movimentos indígenas e as organizações aliadas fizeram diversos encontros e cada um deles versava sobre alguma temática que estava incomodando naquele ano.

A antropóloga Ferreira (2001, p. 90-91) destaca que o evento de 1987, que ocorreu no Rio de Janeiro, foi importante porque conseguiu reunir diversas representações das ONGs e a universidade pública para que se discutisse a temática ligada à educação escolar. Esse evento, "Encontro Nacional de Educação Indígena”, foi promovido pela Fundação Nacional Pró-Memória do Ministério da Cultura, e pelo Museu do Índio do Rio de Janeiro, por meio do Núcleo de Educação Indígena. Citando Ferreira, "Constituíram-se, nessa reunião, Grupos de Trabalho (GTs) para refletir sobre variados temas: Currículo Escolar, Missões Religiosas Proselitistas, Educação Bilingue e Mecanismos de Ação Coordenada". Foi elaborado um documento destinado às autoridades educacionais reclamando a criação, nos Ministérios da Educação e da Cultura, de organismos próprios da educação indígena para

[...] executar, acompanhar e avaliar a implementação de uma política de educação indígena, nova e qualitativamente diferente, formulada com a participação dos povos indígenas, dos educadores e instituições nacionais realmente comprometidos com o destino desses povos (2001, p. 90-91).

Essa citação atesta que, desde a década de 1970, os povos indígenas se movimentam em prol de suas comunidades e para fortalecer suas culturas tão desacreditadas e desrespeitadas. E é percebida na reivindicação documental, uma educação escolar diferenciada para os povos indígenas. Os movimentos indígenas apoiados pelas ONGs, 
universidades públicas continuaram a marcha para a defesa dos seus direitos. Essa força foi turbinada com a conquista de uma Constituição Federal (1988) que lhes assegurou esses direitos.

Todas essas trajetórias que não vamos aprofundar (pois já estão muito debatidas), desembocaram em uma questão interligada ao tema da educação escolar indígena - a formação de professores indígenas. Então, surgiram os magistérios indígenas. No Brasil inteiro, começaram iniciativas de formação de professores indígenas para ministrar aulas em suas comunidades.

Outro problema ligado à escolarização afligia as comunidades indígenas: onde encontrar professores que tivessem comprometimento e conhecimento das sociedades indígenas para trabalhar nas aldeias? Começava uma nova saga. Professores não indígenas não se acostumavam com a vida nas aldeias e, a cada ano, quando se conseguia algum(a) professor(a), este(a) não ficava nem um mês e já pedia para ir embora. Mais uma argumentação para a formação de professores indígenas.

Ao término das primeiras turmas formadas no $\mathrm{Ma}-$ gistério, novamente havia necessidade de prosseguir com a formação de professores. Onde? O que fazer? E foi assim, com esses movimentos indígenas, que foi criado um Projeto de Formação de Professores Indígenas no $3^{\circ}$ Grau Indígena na Universidade Federal de Mato Grosso UNEMAT. Por tornar-se a universidade pioneira no Brasil, diversas etnias do país vieram procurar vagas para concorrer ao vestibular. Foram abertas 200 vagas, sendo 180 para o Estado de Mato Grosso e o restante distribuído nos outros estados brasileiros. Mas essa demanda ocorreu somente com a primeira turma. Da segunda turma em diante, somente participaram povos do Estado de Mato Grosso.

De acordo com o historiador e antropólogo Januário (2012), em 1996 foi plantada a semente sobre formação de professores indígenas com o início do Curso de Magistério Específico e Diferenciado denominado "Projeto Tucum" e foi dessa experiência que surgiu o Projeto $3^{\circ}$ Grau Indígena - uma parceria entre UNEMAT, FUNAI e SEDUC. Esse projeto pioneiro no país iniciou suas atividades em 2001, ofertando as três primeiras Licenciaturas Específicas - Ciências Matemáticas da Natureza; Ciências Sociais e Línguas, Artes e Literatura para indígenas e abarcando um universo de trinta e seis etnias.

Como curso superior pioneiro no Brasil, o $3^{\circ} \mathrm{Grau}$ Indígena foi puxando a fila de outros cursos específicos em outros Estados da Federação que iniciaram, também, essa formação de professores. Desse modo, muitos professores e professoras estão com formação de curso superior e dão aulas em suas comunidades. Um problema, contudo, na educação escolar nas aldeias continua: o que é mesmo para ser educação escolar indígena? Essa pergunta é sempre repetida todas as vezes que se olha a prática pedagógica nas aldeias e o movimento dos conteúdos e dos procedimentos 
metodológicos, pois, em geral, são os mesmos utilizados para a sociedade não indígena.

Com as reivindicações dos movimentos indígenas e de seus aliados não indígenas, surgiu a maior conquista da educação escolar para povos indígenas: as universidades públicas apoiadas pelo MEC passaram a oferecer cursos de formação específica para povos indígenas em todo o país. Depois, surgiram outras formas para os indígenas cursarem outros cursos superiores, como as vagas adicionais e as cotas de ação afirmativas, e entraram também as universidades particulares nessa disputa de bolsas para ampliar seus cursos para afros, quilombolas e indígenas.

As universidades se orgulham de terem, em seu seio, uma formação específica para professores indígenas ou mesmo de disponibilizarem vagas para indígenas. Então, será que com a formação superior de professores indígenas foi resolvido o problema conflituoso nas comunidades indígenas? Não. Mas onde está o fio que conduz esse problema? Algumas hipóteses: Está na formação inicial de professores indígenas? Caso se confirme, há um problema sério para as universidades resolverem. O problema é linguístico? Também as universidades têm que ficar preocupadas. São problemas de relações interculturais? Os estudantes indígenas não conseguem viver fora do seu espaço, da sua cultura, dos seus costumes? Estudantes e professores não indígenas não conseguem perceber e receber culturas diferentes da sua? Todos os caminhos levam os problemas para as universidades. O que fazer?

Evidentemente, os problemas não são apenas das universidades. São gerados pela falta de respeito com as culturas que não sejam do ocidente. Eles vêm do período da colonização e a sociedade brasileira não consegue "vestir outra roupa' que não seja a colonizadora. Esses problemas, portanto, estão em toda parte: dentro das universidades, na rua, nos espaços públicos e religiosos. Foram mais de 500 anos de aprendizado e isso ficou arraigado como uma forte raiz na terra. Todas as conquistas já publicadas por diversos autores e diferentes áreas mostram que é possível descolonizar-se; mas, inicialmente, deve-se mudar essa roupa velha que não cabe mais nos corpos do Brasil atual.

Outro problema de aceitação dos povos indígenas é a terra, pois os territórios que são sagrados para os indígenas e são vistos somente como fonte de lucros para alguns da sociedade brasileira. Tudo é questão da educação. É preciso educar as pessoas e, especialmente, reconhecer a necessidade de encontar novos horizontes, de criar novas políticas públicas para o Brasil.

Do lado das comunidades indígenas, há o desejo de estudar. Há cursos de licenciatura ou bacharelados, formação de professores, possibilitando que tornem-se médicos, advogados, engenheiros etc.. Todavia, é preciso procurar os grandes centros para isso. Assim, a saída da aldeia 
já é um trauma. Como deixar a família? E os costumes alimentares, as culturais e outras diferenças desse viver que fora das comunidades não são reconhecidos?

Da parte das universidades públicas há um interesse de oferecer cursos. Mas faltam professores compromissados com os povos indígenas, com os quilombolas; afinal, a universidade está acostumada com estudantes padrão: falantes da língua portuguesa, que têm os mesmos costumes e conhecem bem a cultura da sociedade ocidental.

Nos últimos anos, outro problema assombra as comunidades indígenas: seus jovens saem para estudar na cidade e muitos não querem voltar para suas aldeias quando terminam o curso. Então, é preciso que as comunidades também repensarem suas ações para minimizar esse problema.

\section{CONSIDERAÇÕES FINAIS}

O texto, desde o início, procura orientar a leitura para três elementos básicos e conflituosos no contexto da sociedade brasileira, seja ela indígena ou não indígena. Os três precisam complementar-se. O território está interligado com a educação indígena. A educação indígena precisa oferecer de novo sua mão à educação escolar. Mas o temor e a desconfiança ainda persistem. Como aliar na vida uma velha inimiga?

Na busca de minimizar os problemas interligados à educação escolar para que ela se torne educação escolar indígena, é preciso encontrar a interculturalidade. O filósofo Merleau-Ponty (2006, p. 16) afirma que "compreender é reapoderar-se da intenção total" e que a dimensão da história é a relação com o Outro. Com esse mesmo entendimento, acrescenta que a compreensão é "[...] a fórmula de um comportamento único em relação ao outro, à natureza, ao tempo e à morte, certa maneira de por forma no mundo que o historiador deve ser capaz de retomar e de assumir".

Assim, as universidades que oferecem formação inicial com cursos específicos para professores indígenas têm tempo de se prepararem para esse comprometimento, de assumirem essa dimensão histórica com sua complexidade. Resta, ainda, perceber que a educação como toda a vida é relação. Relação que pressupõe cuidado, cura, convivialidade e risco.

Trazemos a ambiguidade dentro de nós. A pessoa do educador tem peso grande no processo educacional. Ignorá-lo é pretender que se possa educar sem liberdade, sem reconhecimento, sem cuidado e com consciência da limitação pessoal e da impossibilidade absoluta de poder garantir a vida, que possui um princípio de autonomia que nos transcende.

O mais importante disso tudo é a conquista dessas forças que movem esses povos indígenas para ir em frente para conseguir aquilo que eles sempre sonharam. É preciso que as universidades sejam um pouco mais humildes, que 
queiram saber e se formar com seus estudantes indígenas. É preciso que os professores das universidades escutem mais, estejam abertos para esse outro aprendizado; mas, para isso, é preciso "mudar de roupa". Há que se vestir de amor, de humildade, de comprometimento e fortalecer as raízes junto às comunidades indígenas e buscar o aprendizado mútuo. Somente nesse querer dialogar com uma relação de respeito de ambas as partes que é possível dialogar e fazer a interculturalidade. Só que o caminho também passa por vias espirituais e é deve valorizar a cultura e a religiosidade do "Outro de mim".

\section{REFERÊNCIAS}

AMOROSO, M. R. Mudanças de hábito: catequese e educação para índios nos aldeamentos capuchinhos. In: SILVA, A. L. da; FERREIRA, M. K. L. (Org.). Antropologia, História e Educação: a questão indígena e a escola. São Paulo, 2001. p. 133-156.

ASSARÉ, Patativa. Cante Lá que Eu Canto Cá - Filosofia de um Trovador Nordestino - $17^{\mathrm{a}}$ Ed. Vozes, 2011

CAPALBO, C. Fenomenologia das ciências Humanas. Aparecida: Ideias \& Letras, 2008.

CARON, M. M. Fundamentos de Geografia Escolar Natureza e espaço social nas séries iniciais: "Dos segredos da natureza à complexidade do espaço”. Cuiabá: Central de Texto/EdUFMT, 2012.

FERREIRA, S. de S. Agamben e a vida nua: produto final da máquina antropológica. IHU Online. Ed. 239. Ano VII, 08.10.2007. Disponível em: <http://www.ihuonline. unisinos.br/index.php?option=com_content\&view=articl e\&id=1385\&secao=239> . Acesso em: 12 dez. 2014 .

GALLOIS, Dominique Tilkin. Terras ocupadas? Territórios? Territorialidades?. [s. d.]. Disponível em: $<$ http://pib.socioambiental.org/files/file/PIB_institucional/dgallois-1.pdf> . Acesso em: 12 dez. 2014.

GUIMARÃES, Solange T. de Lima, et. al. RuAção: das epistemologias das ruas à política das ruas. (organizadores.) EdUFMT, Editora Sustentável: Cuiabá, 2014.

JANUÁRIO, E. Ensino Superior para índios: um novo paradigma na educação. Cadernos de Educação Escolar Indígena. $3^{\circ}$ Grau Indígena, v. 1 , n. 01, 2002. Barra do Bugres, p. 15-16.

LUCIANO, G. dos S. O índio brasileiro: o que você precisa saber sobre os povos indígenas no Brasil de hoje. Brasília: Ministério da Educação, Secretaria de Educação 
Continuada, Alfabetização e Diversidade; LACED/Museu Nacional, 2006. Disponível em: <http://unesdoc.unesco. org/images/o015/o01545/154565por.pdf>. Acesso em: 12 dez. 2014 .

MELIÁ, Bartomeu. Educação indígena na escola. Cadernos Cedes, ano XIX, $n^{0} 49$, Dezembro/99

MERLEAU-PONTY, M. Fenomenologia da percepção. 3. ed. São Paulo: Martins Fontes, 2006.

O visível e o invisível. São Paulo: Perspectiva, 2009.

Signos. 1. ed. São Paulo: Martins Fontes, 1991.

OLIVEIRA, João Pacheco; FREIRE, Carlos Augusto da Rocha. A Presença Indígena na Formação do Brasil Brasília: Ministério da Educação, Secretaria de Educação Continuada, Alfabetização e Diversidade; LACED/Museu Nacional, 2006.

RUIZ, C. M. M. B. A sacralidade da vida na exceção soberana, a testemunha e sua linguagem. (Re)leituras biopolíticas da obra de Giorgio Agamben. Cadernos IHU, ano 10, n. 39, p. 1-55, maio 2012. Disponível em: <http://www.ihu.unisinos.br/images/stories/cadernos/ihu/o39cadernosihu. pdf >. Acesso em: 12 dez. 2014.

SOUSA SANTOS, Boaventura.O direito dos oprimidos. São Paulo: Editora Cortez, 2014. 